\title{
Multicentennial Variability of the Sea Surface Temperature Gradient across the Subpolar North Atlantic over the Last 2.8 kyr*,+
}

\author{
ARto MietTinen \\ Norwegian Polar Institute, Troms $\varnothing$, Norway \\ DMITRY DIVINE \\ Department of Mathematics and Statistics, University of Troms $\phi$, Troms $\phi$, Norway \\ NALAN KOÇ \\ Norwegian Polar Institute, and Department of Geology, University of Troms $\phi$, Troms $\phi$, Norway \\ FRED GODTLIEBSEN \\ Department of Mathematics and Statistics, University of Troms $\varnothing$, Troms $\varnothing$, Norway \\ IAN R. HALL \\ School of Earth and Ocean Sciences, Cardiff University, Cardiff, United Kingdom
}

(Manuscript received 27 July 2010, in final form 8 December 2011)

\begin{abstract}
A 2800-yr-long August sea surface temperature (aSST) record based on fossil diatom assemblages is generated from a marine sediment core from the northern subpolar North Atlantic. The record is compared with the aSST record from the Norwegian Sea to explore the variability of the aSST gradient between these areas during the late Holocene.

The aSST records demonstrate the opposite climate tendencies toward a persistent warming in the core site in the subpolar North Atlantic and cooling in the Norwegian Sea. At the multicentennial scale of aSST variability of $600-900 \mathrm{yr}$, the records are nearly in antiphase with warmer (colder) periods in the subpolar North Atlantic corresponding to the colder (warmer) periods in the Norwegian Sea. At the shorter time scale of 200-450 yr, the records display a phase-locked behavior with a tendency for the positive aSST anomalies in the Norwegian Sea to lead, by $\sim 30 \mathrm{yr}$, the negative aSST anomalies in the subpolar North Atlantic. This apparent aSST seesaw might have an effect on two major anomalies of the European climate of the past Millennium: Medieval Warm Period (MWP) and the Little Ice Age (LIA). During the MWP warming of the sea surface in the Norwegian Sea occurred in parallel with cooling in the northern subpolar North Atlantic, whereas the opposite pattern emerged during the LIA.

The results suggest that the observed aSST seesaw between the subpolar North Atlantic and the Norwegian Sea could be a surface expression of the variability of the eastern and western branches of the Atlantic meridional overturning circulation (AMOC) with a possible amplification through atmospheric feedback.
\end{abstract}

\footnotetext{
* European Project for Ice Coring in Antarctica (EPICA) Publication Number 281.

${ }^{+}$Supplemental information related to this paper is available at the Journals Online website: http://dx.doi.org/10.1175/JCLI-D-11-00581.s1
}

Corresponding author address: Arto Miettinen, Norwegian Polar Institute, Fram Centre, NO-9296 Troms $\varnothing$, Norway.

E-mail: arto.miettinen@helsinki.fi

\section{Introduction}

Variability of sea surface temperature (SST) in the North Atlantic and the Nordic Seas has a profound effect on climate in Europe and adjacent areas (e.g., Bjerknes 1964) due to heat release to the atmosphere from the North Atlantic Current (NAC). The NAC itself is a surface expression of the Atlantic meridional overturning circulation (AMOC) - an essential component 
of the global climate system (Vellinga and Wood 2002)-transporting heat northward via the NAC and ventilating the World Ocean through North Atlantic Deep Water (NADW) formation.

The AMOC and regional climate are closely linked (e.g., Latif et al. 2004) and known to vary in the broad range of time scales from subannual (Cunningham et al. 2007) to millennial (Bianchi and McCave 1999; Thornalley et al. 2009). The intra- to multiannual variability is primarily driven by the atmosphere (Marshall et al. 2001), whereas at longer time scales, the role of the ocean becomes more important (e.g., Bjerknes 1964; Knight et al. 2005). Variations in the advection of sea ice and polar water from the Arctic modulate the vigor of the AMOC and, hence, regional SST (Mauritzen and Häkkinen 1997; Greene et al. 2008). The increased freshwater fluxes may reduce or even shut down deep convection, which forms NADW water masses in the Labrador and Nordic Seas, leading to a slowing of the AMOC and regional cooling (Dahl et al. 2005; Greene et al. 2008). These variations have occurred on widely different time scales from decadal to centennial and millennial and have had major impacts on the North Atlantic climate (e.g., Bond et al. 1997; Andrews and Giraudeau 2003).

The late Holocene is a period of relatively stable climate in the context of the large-amplitude, millennialscale fluctuations of the glacial period observed in the Greenland and Antarctic ice core records (e.g., Dansgaard et al. 1993; EPICA Community Members 2006) as well as marine records (Bond et al. 1997). However, suborbitalscale variability has occurred throughout the Holocene, but the nature and the forcing mechanisms of this variability are not well constrained (Denton and Karlén 1973; Bond et al. 1997; Bianchi and McCave 1999; deMenocal et al. 2000; Berner et al. 2008; Divine et al. 2010). Historical records and proxy climate data from the Northern Hemisphere have provided evidence for the most recent major climate anomalies, like the warm Medieval warm period (MWP) between AD 800 and 1400 (e.g., Lamb 1965; Bradley et al. 2003; Mann and Jones 2003; Berner et al. 2011), and the following colder era, the Little Ice Age (LIA) between AD 1400 and 1900 (Grove 1988; Bradley and Jones 1993; Moberg et al. 2005; Mann et al. 2008).

Several theories have been proposed to explain the possible cause for these anomalies, such as long-term variability in total solar irradiance (TSI) (Shindell et al. 2001; Renssen et al. 2006), sulfate aerosols ejected into the atmosphere by volcanism (Crowley 2000; Shindell et al. 2003; Otterå et al. 2010), and changes in largescale ocean circulation (Broecker 2000; Crowley 2000). Although there has been uncertainty regarding the role of solar forcing (Hegerl et al. 2007), the recent modeling studies have found the mechanisms of positive feedbacks in the ocean-atmosphere system that may amplify the response to TSI variations (Bond et al. 2001; Weber et al. 2004; Renssen et al. 2006; Swingedouw et al. 2011).

To investigate the SST variability in the subpolar North Atlantic, we reconstructed August sea surface temperature (aSST) with a high-resolution based on diatom assemblages in a 2800-yr-long composite sediment core from the eastern flank of Reykjanes Ridge. The principal time scales of the variability and the most prominent warming/ cooling events of the late Holocene in the area were identified by spectral and scale-space methods. The results were then compared with the previously published aSST record from the Vøring Plateau in the Norwegian Sea (Andersen et al. 2004a; Berner et al. 2011). The variability of the aSST gradient between these two sites was analyzed and then placed in the context of possible past changes in the oceanic circulation.

\section{Oceanographic setting}

The subpolar North Atlantic is an oceanographically dynamic area. The surface limb of the AMOC transports warm and saline Atlantic waters (the Atlantic inflow) northeastward via the surface NAC across the North Atlantic into the Nordic Seas (the Greenland, Iceland, and Norwegian Seas), passing between the subpolar (SPG) and subtropical (STG) gyres, from which it draws water (Fig. 1). SPG and STG affect on the location, intensity, and composition of the NAC in the subpolar North Atlantic (Hátún et al. 2005; Thornalley et al. 2009). The NAC has two major northeastward flowing surface branches, which form the major northward pathways of the Atlantic inflow in the subpolar North Atlantic; the western branch through the Iceland Basin, and the eastern branch through the Rockall Trough as the Continental Slope Current (CSC) (Fratantoni 2001). The western branch of the NAC bifurcates south of Iceland into the southwest flowing Irminger Current (IC) and the northeast flowing Faroe Current (FC), which forms north of the Faroe Islands the western branch of the Norwegian Atlantic Current (NwAC, Fig. 1). Most of the IC consists of a strong current southward along the eastern slope and subsequently northeastward flow along the western slope of the Reykjanes Ridge (Orvik and Niiler 2002). It continues westward, turns south, flows parallel to the cold East Greenland Current (EGC) down to Cape Farewell on the southern Greenland tip, and is finally incorporated into the West Greenland Current (WGC). Part of the IC flows anticyclonically around Iceland to the North Icelandic Shelf (Hansen and Østerhus 2000). Today, the core site in the Reykjanes Ridge is primarily influenced by the NAC and SPG. The eastern branch of 


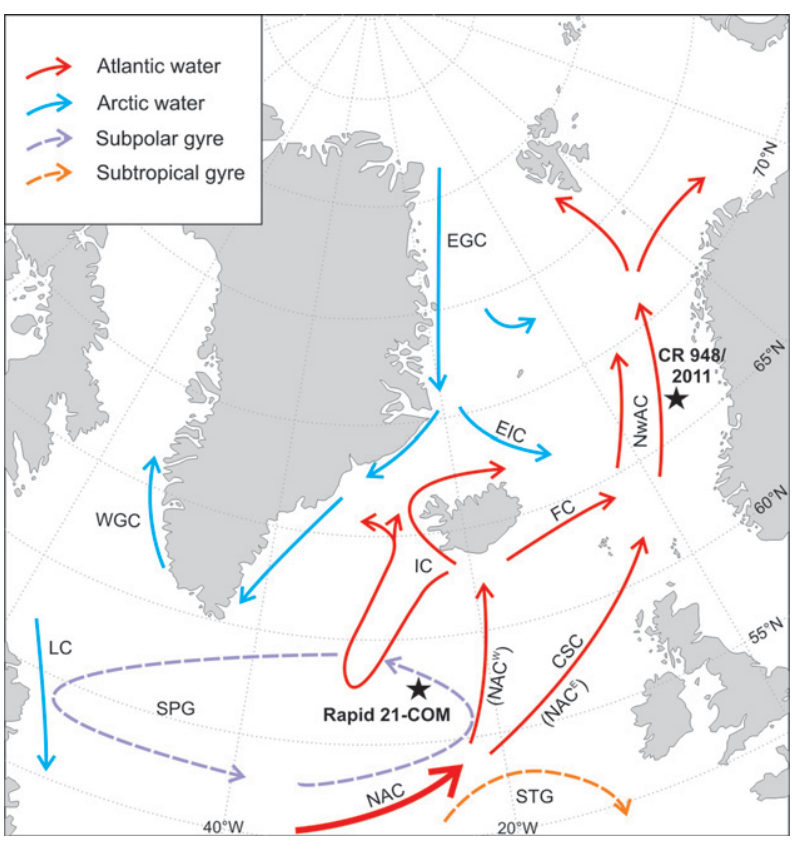

FIG. 1. Location of the core sites Rapid 21-COM in the Reykjanes Ridge and CR 948/2011 in the Vøring Plateau. The modern surface ocean circulation pattern in the North Atlantic and the Nordic Seas showing the NAC: North Atlantic Current $\left(\mathrm{NAC}^{\mathrm{W}}\right.$ : the western branch, $\mathrm{NAC}^{\mathrm{E}}$ : the eastern branch), IC: Irminger Current, FC: Faroe Current, CSC: Continental Slope Current, NwAC: Norwegian Atlantic Current, EGC: East Greenland Current, EIC: East Icelandic Current, WGC: West Greenland Current, LC: Labrador Current, SPG: subpolar gyre, and STG: subtropical gyre. The figure is modified from Ruddiman and Glover (1975), Hansen and Østerhus (2000), and Orvik and Niiler (2002).

the NAC, the CSC, is the most saline and warmest current flowing over the Greenland-Scotland Ridge (Hansen and $\varnothing$ sterhus 2000). It forms the eastern branch of the NwAC in the Norwegian Sea (Orvik and Niiler 2002), where the Vøring Plateau (and another core site) is located under the direct influence of the NwAC.

\section{Material and methods}

Two marine sediment cores were used in this study: Rapid 21-COM from the Reykjanes Ridge, the Iceland Basin, in the subpolar North Atlantic, and CR 948/2011 from the Vøring Plateau, the Norwegian Sea (Fig. 1). Core Rapid 21-COM represents a composite of two individual sediment cores (Rapid 21-12B and Rapid $21-3 \mathrm{~K})\left(57^{\circ} 27.09^{\prime} \mathrm{N}, 27^{\circ} 54.53^{\prime} \mathrm{W} ; 2630-\mathrm{m}\right.$ water depth), which were recovered from the southern limb of the Gardar Drift on the eastern flank of Reykjanes Ridge during the RRS Charles Darwin cruise 159 in 2004. The age model for core Rapid 21-COM is based on ${ }^{210} \mathrm{~Pb}$ dating for the 54.3-cm-long sediment box-core Rapid 21-12B (Boessenkool et al. 2007) and on accelerator

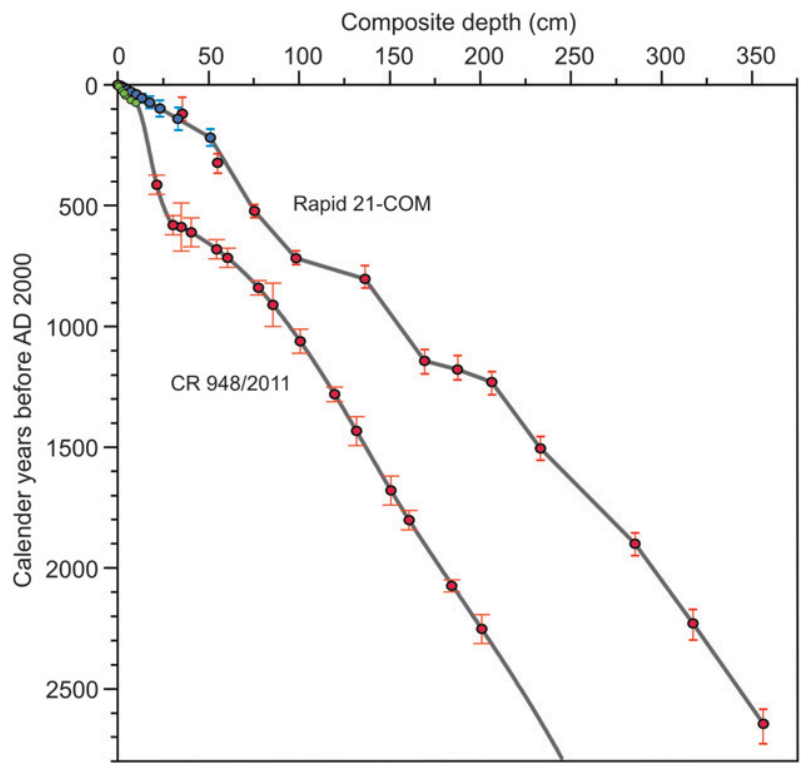

FIG. 2. The age models of the composite cores Rapid 21-COM (modified Boessenkool et al. 2007; Sicre et al. 2011) and CR 948/2011 (modified from Berner et al. 2011). The blue dots represent ${ }^{210} \mathrm{~Pb}$ dates for core Rapid 21-12B and the green ones ${ }^{210} \mathrm{~Pb}$ dates for core CR 948/2011. The red dots represent AMS ${ }^{14} \mathrm{C}$ dates for both of the cores. Vertical error bars show the $1-\sigma$ range on the estimated ${ }^{210} \mathrm{~Pb}$ and ${ }^{14} \mathrm{C}$ dates.

mass spectrometry (AMS) ${ }^{14} \mathrm{C}$ dating for the $372.5-\mathrm{cm}$ long kasten core Rapid 21-3K (Boessenkool et al. 2007; Sicre et al. 2011) (Fig. 2). The composite age model for core Rapid 21-COM shows an average sedimentation rate of $132 \mathrm{~cm} \mathrm{ka}^{-1}$ (Boessenkool et al. 2007; Sicre et al. 2011). The previously published diatom-based aSST record from core Rapid 21-12B has 2-yr-average resolution for the last $230 \mathrm{yr}$ (Miettinen et al. 2011). Core Rapid 21$3 \mathrm{~K}$ was sampled continuously at $1.0-\mathrm{cm}$ intervals and analyzed at 1 - to 5 -cm intervals with a resolution of 8 $10 \mathrm{yr}$ for the interval AD 800-1770, representing the highest-resolution diatom SST reconstruction from the subpolar North Atlantic for this period, and $40 \mathrm{yr}$ for interval 800 BC-AD 800. The composite core CR 948/ 2011 (Andersen et al. 2004a; Berner et al. 2011) from the Vøring Plateau $\left(66^{\circ} 58.18^{\prime} \mathrm{N}, 07^{\circ} 38.36^{\prime} \mathrm{W}\right)$ consists of cores MD95-2011 (Birks and Koç 2002; Berner et al. 2011) and JM97-948/2A (Andersen et al. 2004a). The age model for the core was based on $\mathrm{AMS}{ }^{14} \mathrm{C}$ and ${ }^{210} \mathrm{~Pb}$ dates. Further details of the material and age model are given by Andersen et al. (2004a) and Berner et al. (2011).

Marine planktonic diatoms were used to reconstruct past aSST because they are proven to be good indicators of surface water conditions in the region (Koç-Karpuz and Schrader 1990; Andersen et al. 2004a; Berner et al. 2008). Marine diatoms are single-celled, photosynthetic, 
siliceous-walled algae, which constitute the major part of the phytoplankton thus being major primary producers in oceans. Diatoms are dependent on light for photosynthesis and therefore they live in the uppermost surface waters $(0-50 \mathrm{~m})$. The diatom samples were prepared using the method described by Koç et al. (1993), which consists of $\mathrm{HCl}$ and $\mathrm{H}_{2} \mathrm{O}_{2}$ treatment to remove calcium carbonate and organic matter, clay separation, and preparation of quantitative slides. A Leica Orthoplan microscope with $1000 \times$ magnification was used for identification and counting of diatoms. The counting procedure described by Schrader and Gersonde (1978) was followed. At least 300 diatom frustules (excluding Chaetoceros resting spores) were identified from each sample. Chaetoceros resting spores were excluded because they show negligible sensitivity to SSTs and can be so numerous that they can dominate the diatom assemblage biasing the reconstructions (Koç-Karpuz and Schrader 1990).

A modern training set consisting of 139 surface samples with 52 diatom species from the Nordic Seas and the North Atlantic (Andersen et al. 2004a) was utilized to convert downcore diatom counts to quantitative aSST using the weighted-averaging partial least squares (WAPLS) transfer function method (ter-Braak and Juggins 1993). August SST was chosen because for diatom transfer functions August SST gives the best match (Berner et al. 2008). The WA-PLS method can be regarded as the unimodal-based equivalent of multiple linear regression. This means that a species has an optimal abundance along the environmental gradient being investigated. The WAPLS diatom transfer function has a rms error (RMSE) of $0.75^{\circ} \mathrm{C}$, a coefficient of determination between observed and inferred SST $\left(r^{2}\right)$ of 0.96 , and a maximum bias of $0.44^{\circ} \mathrm{C}$. The WA-PLS method uses several components in the final transfer function. These components are selected to maximize the covariance between the environmental variables to be reconstructed and hence the predictive power of the method. We used four components, which are based on the statistical cross-validation procedure (ter Braak and Juggins 1993).

The Significance of Zero Crossings of the Derivative (SiZer) (Chaudhuri and Marron 1999) was used to explore significant features in the reconstructed SST record at different scales. The main idea of SiZer is that significant features are found at different scales, that is, at different levels of resolution. For illustrating the use of this scale-space methodology, suppose a time series of data points is given. At a specific location, SiZer fits a local linear kernel estimator. Loosely speaking, this means that a straight line is fitted using observations in a neighborhood of the point. The size of the neighborhood has the interpretation of a scale or a level of resolution for which the data are analyzed. At the point under study, several neighborhood sizes are used and, by this procedure, the datasets can be studied at a large number of different scales. A smoothing parameter, entitled $h$, is used to control the size of the neighborhood in the sense that a large $h$ corresponds to a large neighborhood. The Gaussian kernel estimator embedded in SiZer does not require an analyzed time series to be evenly spaced. The method is therefore applied to the data directly without any prior resampling. For a quantitative comparison of the two considered time series a common regular time scale was however generated using a Gaussian kernel estimator to resample the series with a specified degree of smoothing. The choice of the common $h$ was conditioned by a tradeoff between the sampling density and the highest possible level of details retained in the smoothed records.

Many geophysical time series have distinctive red noise characteristics that can be modeled very well by a firstorder autoregressive (AR1) process. Fourier analysis of the data was therefore carried out using the REDFIT technique (Schulz and Mudelsee 2002). The major advantage of the method is that it fits the AR1 process directly to the unevenly spaced time series. Both reconstructed aSST series were detrended prior to analysis. The appropriateness of the AR1 model to describe the analyzed data was tested using a nonparametric runs test (Bendat and Piersol 1986) embedded in the REDFIT package.

The wavelet coherence approach (Torrence and Compo 1998; Grinsted et al. 2004) was used to examine the relationships between the pairs of time series on the different time scales. The method shows how coherent two wavelet spectra being analyzed are and can be thought of as a localized correlation coefficient in time frequency space. Also, the wavelet-transform-based technique was applied for bandpass filtering and visualization of the quasiperiodic behavior of the analyzed records (Torrence and Compo 1998). In both approaches, the Morlet wavelet is used as a basis function. This wavelet is believed to be an optimal choice providing a good balance between time and frequency localization for features in a spectrum. To put two aSST records on the common time scales, they were rebinned by using the time interval of $10 \mathrm{yr}$. The gaps in the resampled series were filled using spline interpolation for creating a time scale with a regular time increment.

\section{Results}

a. Core Rapid 21-COM from the Reykjanes Ridge in the subpolar North Atlantic

The reconstructed 2800-yr-long aSST record for core Rapid 21-COM from the Reykjanes Ridge is shown in Fig. 3. The record shows the total aSST range from $11.9^{\circ}$ 
a)
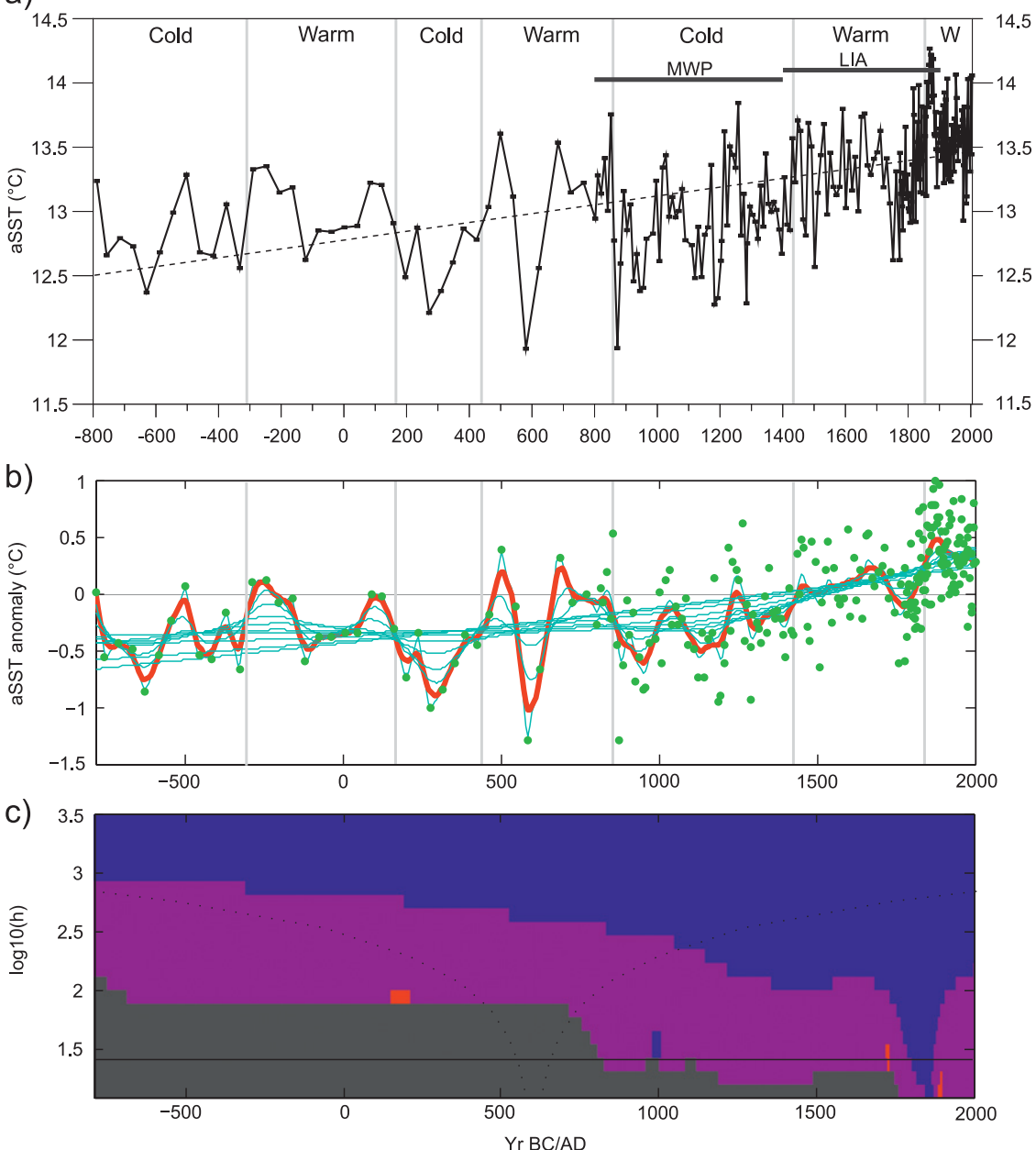

FIG. 3. (a) Reconstructed aSST based on WA-PLS method from core Rapid 21-COM, the Reykjanes Ridge. The dashed line shows a linear trend of the aSST record; solid line segments indicate the MWP: the Medieval Warm Period and LIA: the Little Ice Age, also W: the warmest period of the record. In (b),(c) SiZer reconstruction of the aSST anomalies is shown. (b) Family plot of the aSST anomalies (the anomaly is estimated using the ordinary subtraction of the estimated mean temperature for the whole records from the respective reconstructed SST). The green dots represent the raw data. Blue lines show the smoothing obtained by the local linear kernel estimator. The panel shows a family of smoothings, denoted a family plot. The red smoothing corresponds to a choice of $h$ that typically would be chosen if only one scale were used. It is the result obtained by using the Ruppert et al. (1995) estimate of $h$ in the local linear kernel estimator. Recall from above that in SiZer, the notion of scale is controlled through the bandwidth, $h$ in the kernel estimator. For each scale and location of the signal, a test is performed to see whether the smoothing has a derivative significantly different from zero. In the local linear kernel estimator, this means testing whether the slope at a specific location for a given scale is significantly different from zero. (c) A SiZer map, given as a function of location (time) and scale $h$. A significantly positive (increase) derivative is flagged as blue while a significantly negative (decrease) derivative is flagged as red. The color purple is used at locations where the derivative is not found to be significantly different from zero. The color dark gray is used to indicate that too few data are available to do a correct inference. The distance between the two dotted lines in the cone-shaped curve for a horizontal line in the SiZer plot can be interpreted as the scale for that level of resolution. Owing to the chosen form of the kernel, its length is $4 h$, see Chaudhuri and Marron (1999) for more details. 
a)
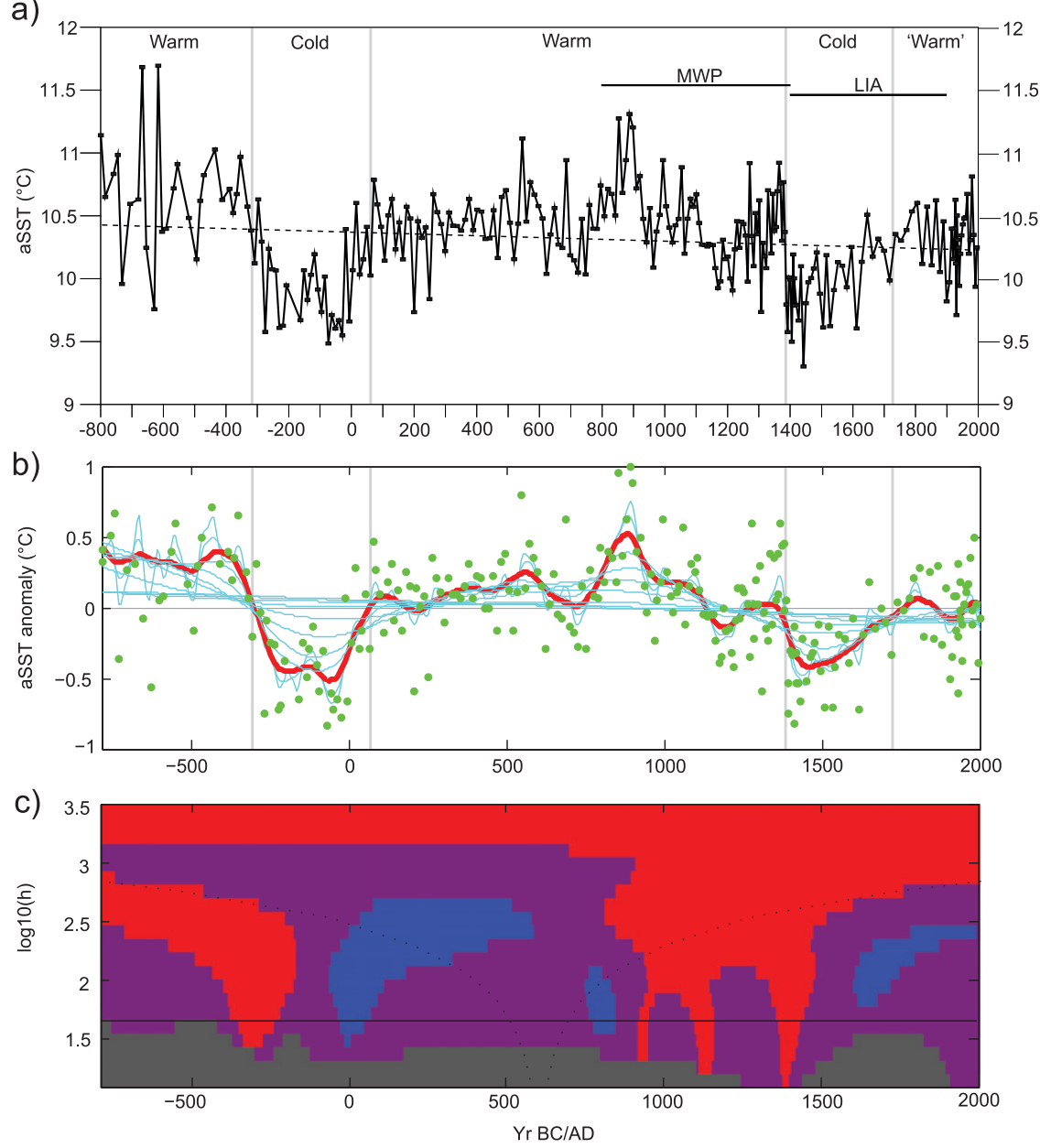

FIG. 4. (a) As in Fig. 3 but for the WA-PLS aSST reconstruction for core CR 948/2011, the Vøring Plateau. The dashed line shows a linear trend of the aSST record, MWP: the Medieval Warm Period and LIA: the Little Ice Age.

to $14.3^{\circ} \mathrm{C}$ and the mean $\mathrm{SST}$ of $13.2^{\circ} \mathrm{C}$. There is a warming trend of $\sim 1^{\circ} \mathrm{C}$ of the surface waters over the Reykjanes Ridge during the last 2800 years. Superimposed on the general warming trend, the record shows clear variability in various time scales (from decadal to multicentennial, see Fig. 5). Centennial variability exists especially during the cold period AD 860-1420, and decadal variability during the warm periods from the fifteenth century to the present.

The aSST record is divided into warm and cold periods based on the reconstructed temperatures above or below the long-term trend. The aSST record begins by a cold period 800-300 BC (Fig. 3), characterized by the mean aSST of $12.8^{\circ} \mathrm{C}$, a minimum aSST $\left(\sim 12.4^{\circ} \mathrm{C}\right) \sim 630$ $\mathrm{BC}$ and a short warmer phase $\sim 500 \mathrm{BC}$ (maximum $\sim 13.3^{\circ} \mathrm{C}$ ). It is followed by a relatively warm period 300 $B C-A D 160$ including warm aSST especially 300-150 $\mathrm{BC}$ and $\sim \mathrm{AD} 100\left(>13.1^{\circ}-13.4^{\circ} \mathrm{C}\right)$. The $\sim 950$-yr-long first third of the record shows a clear warming trend and low-frequency, multicentennial and centennial aSST variability $\left(<1^{\circ} \mathrm{C}\right)$. Cold period $A D 160-450$ represents the coldest period of the entire aSST record in the multicentennial scale (aSST $<13^{\circ} \mathrm{C}$, minimum $\sim 12.2^{\circ} \mathrm{C}$ around AD 270). After this minimum, aSST rises initiating a relatively warm period $A D$ 450-860. After a short cold phase around AD 580, possibly associated with a 1400-yr BP Bond event (Bond et al. 1997), aSST remains at a relatively high level $\left(>13^{\circ} \mathrm{C}\right)$ until $\sim \mathrm{AD}$ 850 , when aSST of $\sim 13.8^{\circ} \mathrm{C}$ is one of the highest ones before the nineteenth century. Cold period AD 8601420 commences from an abrupt drop of aSST. The period is characterized by the dominance of cold waters (the mean aSST $12.9^{\circ} \mathrm{C}$ ) and the centennial-scale variability on the order of magnitude of $\sim 1^{\circ} \mathrm{C}$. The $120-140$-yrlong cold phases prevailed 870-1000, 1080-1200, and AD 1280-1420, and short, $\sim 80$-yr-long warm phases AD 
1000-1080 and 1200-1280. Warm period AD 1420-1850 is characterized by relatively stable and warm aSST (the mean $13.3^{\circ} \mathrm{C}$ ) and decadal variability of $\sim 0.7^{\circ} \mathrm{C}$. Cold aSSTs $\left(<13^{\circ} \mathrm{C}\right)$ are relatively rare occurring only around AD 1500 and occasionally from the 1750s to the 1800s (minima $\sim 12.6^{\circ} \mathrm{C}$ around $\mathrm{AD} 1750$ and 1770). aSSTs $>13.5^{\circ} \mathrm{C}$ are common throughout the period with the warmest years from the 1810 s to the 1840 s (maximum $\sim 14^{\circ} \mathrm{C}$ ). The warmest period AD 1850-2004 is a follow-up for the previous warm period and shows the warmest aSSTs of the entire record with the mean of $13.6^{\circ} \mathrm{C}$. The years $\mathrm{AD}$ 1860-1880 represent the warmest phase of the record (aSST regularly $>14^{\circ} \mathrm{C}$, the record maximum $\sim 14.3^{\circ} \mathrm{C}$ around AD 1870). Further details of the record between AD 1770 and 2004 are given by Miettinen et al. (2011).

\section{b. Core CR 948/2011 from the Vøring Plateau in the Norwegian Sea}

The 2800-yr-long aSST record for core CR 948/2011 (Andersen et al. 2004a; Berner et al. 2011) from the Vøring Plateau is shown in Fig. 4. The record shows a slow cooling trend of $\sim 0.3^{\circ} \mathrm{C}$ of the surface waters during the last $2800 \mathrm{yr}$. Five distinct climatic periods can be discerned in the series: warm period $800-300 \mathrm{BC}$, cold period 300 BC $-\sim$ AD 50, warm period $\sim$ AD 50-1400, cold period AD 1400- 1750, and relatively warm period $\sim \mathrm{AD}$ 1750-1997. The warmest phases prevailed around 800-350 BC (especially 600-700 BC) and AD 800-950. The coldest phases prevailed 300 BC- 0 and AD 1400-1600.

Figure 5 shows the REDFIT spectral estimates for detrended reconstructed aSST from cores CR 948/2011 and Rapid 21-COM. The shape of the spectral continuum is typical for red noise processes. For both series analysis reveals prominent variabilities significantly different from red noise at the $90 \%$ and $95 \%$ confidence levels at the time scales of $<100$ (CR 948/2011), 200-450 $\mathrm{yr}$, and longer than $700 \mathrm{yr}$. The wavelet-based results for these series are presented in supplementary materials that are available online (http://dx.doi.org/10.1175/JCLID-11-0581.s1) and consistent with the inference made from REDFIT spectral estimates. We suggest that a much higher temporal resolution conditions identification of consistent quasi-periodic variations in CR 948/ 2011 aSST series not detected earlier in other proxy data from the same core (Risebrobakken et al. 2003).

\section{Discussion}

a. Late Holocene aSST variability in the Reykjanes Ridge and the Vøring Plateau and its relation to known climate anomalies

The aSST records for core Rapid 21-COM from the Reykjanes Ridge and for core CR 948/2011 from the
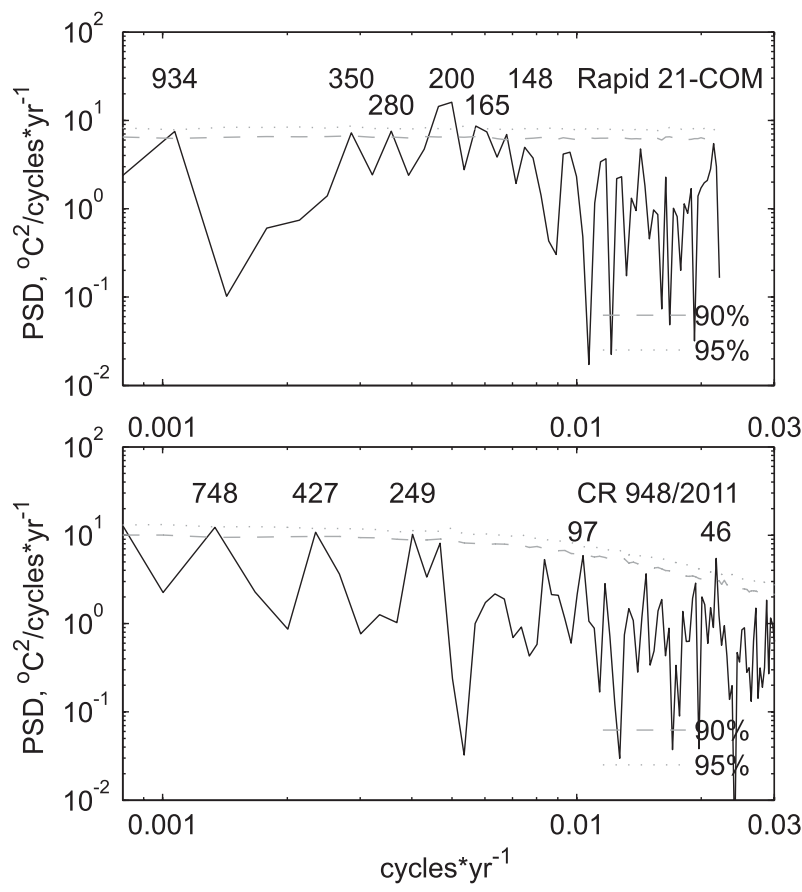

FIG. 5. REDFIT estimates of spectral density function for the detrended reconstructed aSST series (black solid lines), 95\% and $90 \%$ "false alarm" levels (gray dashed and dotted lines, respectively) for the theoretical AR(1) spectrum calculated from the percentiles of the Monte Carlo ensemble.

Vøring Plateau show multicentennial- and centennialscale variability of similar magnitude (Fig. 6). As the most obvious feature one can clearly see that two reconstructed aSST exhibit statistically significant opposite trends: toward warming over the Reykjanes Ridge (Rapid 21-COM) and slow cooling in the Vøring Plateau (CR948/2011). During the last $2800 \mathrm{yr}$, aSST at these sites has increased (decreased) by $0.9^{\circ}$ and $0.3^{\circ} \mathrm{C}$ on average, respectively (Fig. 6a). In the multicentennial scale, the aSST records also tend to be antiphased, that is, during the cold (warm) periods in the Reykjanes Ridge, warm (cold) periods prevail in the Vøring Plateau.

Figure $6 \mathrm{c}$ suggests that the reconstructed aSST record from core Rapid 21-COM aSST shows a significantly larger slope than the record for core CR 948/2011 aSST at the time scale of the whole series (highlighted blue for $\log _{10} h>3$ ) indicating a more pronounced overall tendency to warming in the Reykjanes Ridge area. A blue area over a broad range of scales $\left(\log _{10} h>1.5\right.$; corresponds to a subcentennial time scale and longer) can also be seen around $300 \mathrm{BC}, \mathrm{AD} 1400$, and around AD 1850 highlighting the most distinct periods when CR 948/2011 aSST is decreasing (cooling) and Rapid 21-COM aSST is increasing (warming). The opposite situation, that is, 

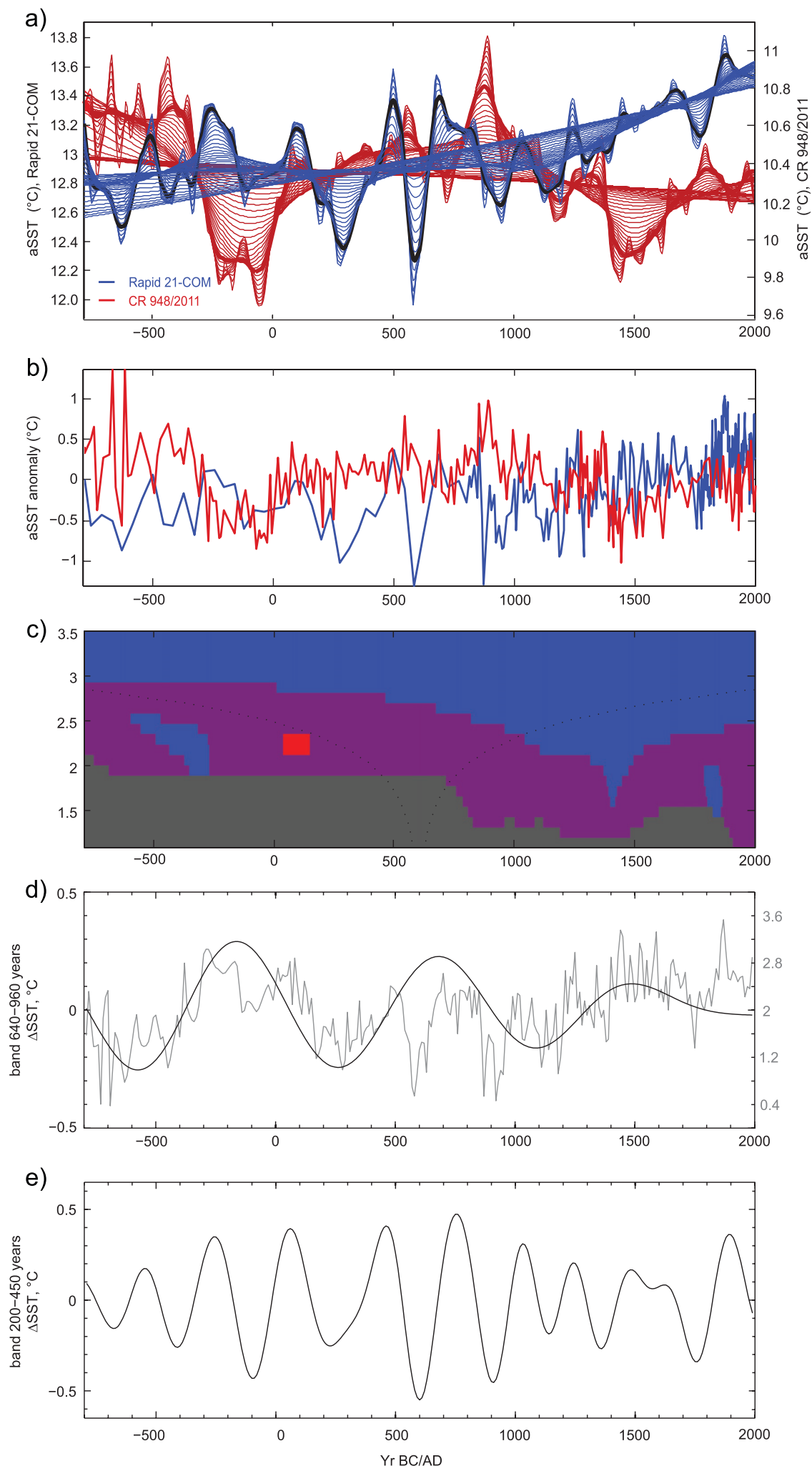

FIG. 6. Comparison of the aSST records of cores Rapid 21-COM and CR 948/2011. (a) Family plots of aSST from cores Rapid 21-COM (blue) and CR 948/2011 (red). (b) aSST anomalies from cores Rapid 21-COM (blue) and CR 948/2011 (red). (c) A modified version of the SiZer 
when Rapid 21-COM aSST has a significantly smaller slope than CR 948/2011 aSST, occurs only around AD 100 (highlighted red) when both of the records show a warming trend. These results are indicative of especially pronounced quasi-synchronous (i.e., with the chronological uncertainties in mind) events in two core sites, and presumably the study areas, to be associated with cooling in the Vøring plateau and warming in the Reykjanes Ridge.

The shifts in the dominant diatom assemblages (not shown) further reveal the changes in oceanographic conditions accompanying the cooling/warming episodes at the core sites. The coolings are generally associated with increased abundances of the subarctic and Arctic Greenland assemblages (factors 3 and 1 in Andersen et al. 2004a), whereas during warm periods, the sites are flooded by warmer and saline waters originating from the NAC (factors 2 and 4).

Several historically well-known climatic periods of the late Holocene, such as the MWP and the LIA, can be easily discerned in the aSST records. The highest aSST in the Norwegian Sea occurred between AD 850 and 900 at the start of the MWP, in parallel with a cool period including one of the coldest aSST events in the subpolar North Atlantic during the late Holocene (Figs. 6a and $3 a)$. Around AD 1400, a blue feature in the SiZer reconstruction kicks in for many scales caused by the fact that CR 948/2011 aSST is rapidly decreasing (cooling) while Rapid 21-COM aSTT is increasing (warming) (Fig. 6c). aSST cooled rapidly $>1{ }^{\circ} \mathrm{C}$ in the Norwegian Sea around AD 1400, which corresponds to the onset of the LIA. Summer sea surface temperatures remained cold in this area until the eighteenth century. Meanwhile in the northern subpolar North Atlantic, aSST show almost a persistent warming trend for the same period, as indicated by the SiZer map (Fig. 3c). Another prominent cool period in the Norwegian Sea took place between $300 \mathrm{BC}$ and $\mathrm{AD} 0$ with rapid transitions of $>1^{\circ} \mathrm{C}$ into and out of this period (Fig. 4), which again is characterized by warming in the subpolar North
Atlantic. Compared with the warm (MWP) and cold (LIA) climate periods from NW Europe, the aSST record from the Reykjanes Ridge reveals opposite temperature patterns (Fig. 3). Most of the MWP was characterized by colder summer surface waters. Correspondingly, the LIA was characterized by one of the warmest periods recorded of the Rapid-21COM aSST record. Notably, the timing of the temperature maximum in Rapid-21COM aSST is in phase with a period of observed sea ice cover expansion in the Nordic Seas (Divine and Dick 2006). These results suggest the variability of the aSST gradient in the NE Atlantic sector may be linked with one of the causal factors for wellknown climate anomalies such as the MWP and the LIA in NW Europe (Fig. 7).

Figure 6d displays the variability of the aSST difference $(\Delta \mathrm{aSST})$ between the two core sites, which is an estimate for the temperature gradient between the Reykjanes Ridge and the Vøring Plateau. The $\Delta$ aSST varies between $0.1^{\circ}$ and $3.6^{\circ} \mathrm{C}$ and demonstrates a pronounced multicentennial variability, which is statistically significant in the bands of 200-450 and 640-960 yr (Figs. 6d,e) according to the wavelet analysis (see Fig. S3). These two bands contribute some $27 \%$ to the overall variance of the constructed $\Delta \mathrm{aSST}$ series. The highest gradients $\left(>2.4^{\circ} \mathrm{C}\right)$ occur $300 \mathrm{BC}-\mathrm{AD} 0$ and from circa $\mathrm{AD} 1400$ to the present. The record level of $\sim 3.6^{\circ} \mathrm{C}$ attained at around AD 1450 and the second contemporary maximum of $3.2^{\circ} \mathrm{C}$ occurred as late as in the nineteenth century before the termination of the Little Ice Age. The latter period of the high gradient has lasted $\sim 600 \mathrm{yr}$, which is longer than elsewhere in the record.

The estimated correlation coefficient between the resampled and detrended Rapid 21-COM and CR 948/ 2011 records of -0.16 is negative but barely significant. However, a relatively low correlation coefficient could also be due to the age uncertainties inherent to the reconstructed aSST.

To isolate statistically significant variations in the bands of 200-450 and 640-960 yr detected in CR 948/2011 and

\footnotetext{
map is used to compare the behavior of two different time series that cover the same period of time. The traditional SiZer plot is replaced by a plot that shows where two time series have significantly different slopes. A significantly positive (increase) derivative of the Rapid 21COM record in relation to the CR 948/2011 record is flagged as blue while a significantly negative (decrease) derivative is flagged as red. The color purple is used at locations where the derivative is not found to be significantly different from zero. The color dark gray is used to indicate that too few data are available to do correct inference. (d) Variability of the aSST gradient between Rapid 21-COM and CR 948/2011 core locations (gray). Solid black line shows $\Delta$ aSST filtered with a wavelet bandpass filter in the band widths of (d) 640-960 yr and (e) 200$450 \mathrm{yr}$.
} 

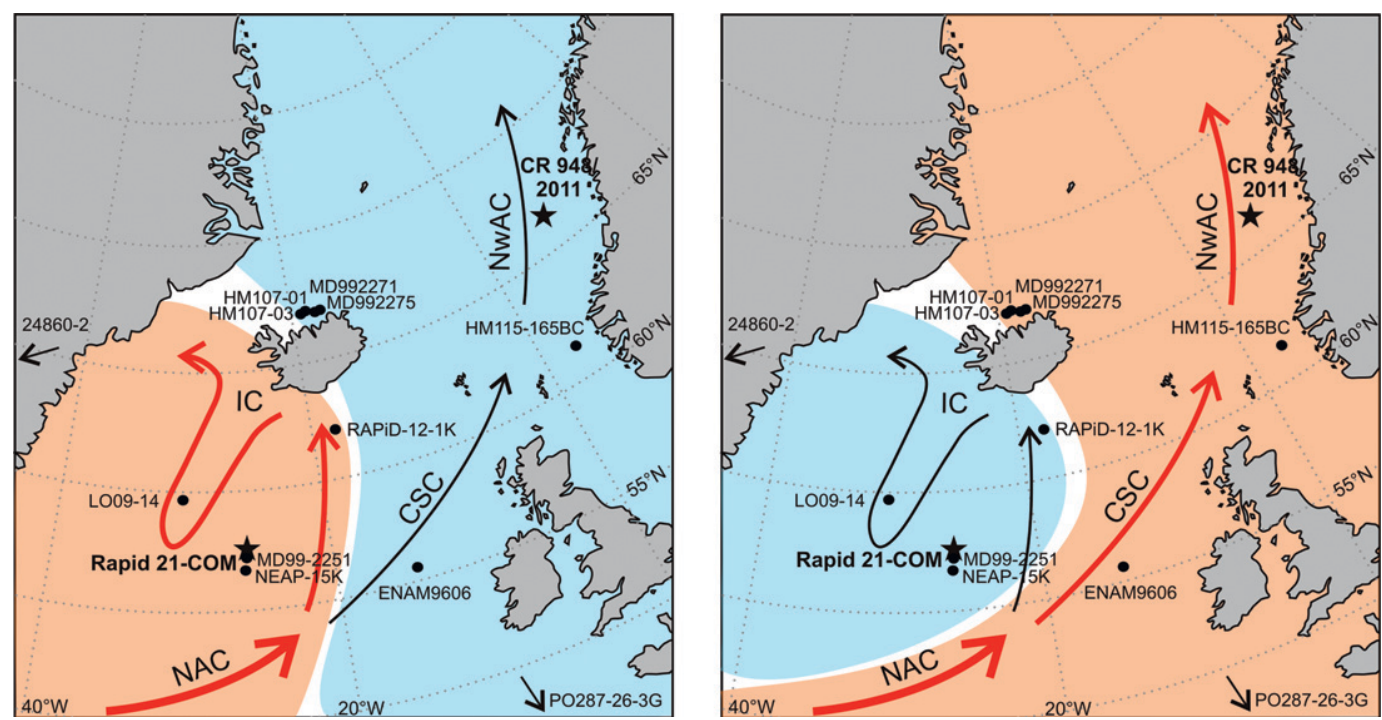

FIG. 7. A schematic map showing the relative aSST patterns during (left) the cold periods (e.g., the LIA) and (right) the warm periods (e.g., the MWP) in northwest Europe. Red arrows indicate surface currents with higher heat flux, orange (blue) shading indicates warm (cool) surface waters, and black circles indicate locations of other cores referred to in the text.

Rapid 21-COM aSST, the signals were bandpass filtered in the respective frequency ranges following the technique described by Torrence and Compo (1998). Except for the most recent $500 \mathrm{yr}$, Fig. 8b shows nearly antiphase variations for reconstructed aSSTs in Rapid 21COM and CR 948/2011 in the scale of 640-960 yr. At the shorter time scales of 200-450 yr (Fig. 8a), the phasing is less clear though the general tendency of the series to be in the opposite phases prevails. The lagged correlation analysis reveals that the maximum correlation of -0.5 between the bandpassed series at these time scales is reached with the lag of $\sim 30 \mathrm{yr}$ (CR948/2011 leads). However, due to the possible errors in the age models of the proxy series as well as lower sampling density in the earlier part of Rapid 21-COM reconstructed aSST, the presence of this lag should be interpreted with a caution. The lag indicates that the negative relationship between aSST fluctuations observed in a millennial-scale perspective is also valid for the time scales down to the bicentennial. The unambiguous inference for even shorter time scales is however difficult to make due to the shortcomings inherent to the proxy-based aSST reconstruction techniques applied.

\section{b. Comparison with the proxy-based late Holocene SST reconstructions from the subpolar North Atlantic and adjacent oceans}

Analysis of available proxy reconstructions of summer sea surface conditions also reveals a spatially heterogeneous pattern of the late Holocene climate across the northern North Atlantic. The late Holocene summer SST decline in CR948/2011 is a continuation of cooling that commenced as early as around 7-kyr BP at the termination of the Holocene thermal optimum (Berner et al. 2011). A similar climate tendency associated with decreasing orbitally forced insolation throughout the Holocene is also revealed in a number of other proxy records across the northeastern North Atlantic (Koç et al. 1993; Koç and Jansen 1994; Eiríksson et al. 2000; Klitgaard-Kristensen et al. 2001; Marchal et al. 2002)
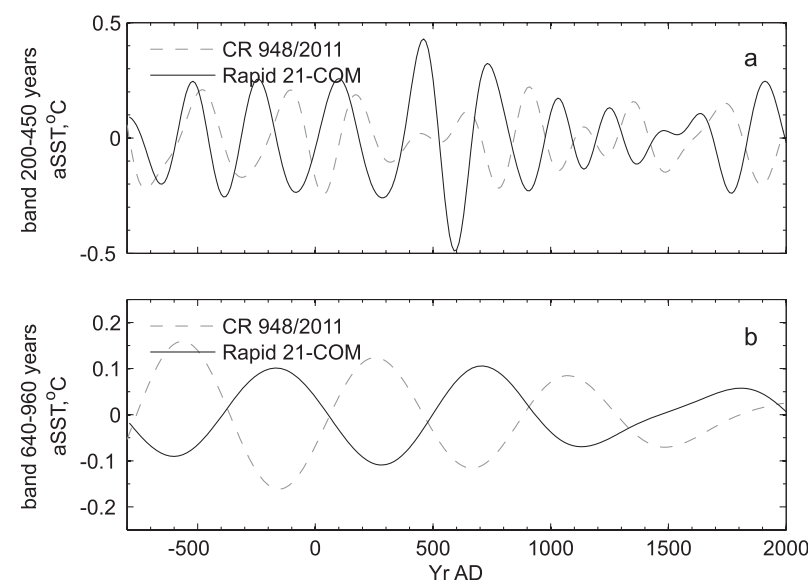

FIG. 8. Variability of the reconstructed aSST series from Rapid 21-COM (black) and CR 948/2011 (dashed gray) cores filtered with a wavelet bandpass filter in the band widths of (a) 200-450 yr and (b) 640-960 yr. 
and corroborated by modeling results (Andersson et al. 2010).

For the last two millennia, most of the proxy records from the northeastern subpolar North Atlantic show higher SST for the MWP period until AD 1400 followed by cooler SST for most of the LIA period (e.g., Eiríksson et al. 2006; Richter et al. 2009). Results for the last $\sim 200 \mathrm{yr}$ differ more, for example, as SST from Feni Drift shows cooling (Richter et al. 2009) but SST from the Iberian Margin shows warming (Eiríksson et al. 2006) for this most recent interval. The previous records from the northeast subpolar North Atlantic are relatively well compatible with the aSST record from the Vøring Plateau suggesting similar SST pattern for the northeast subpolar North Atlantic and the Norwegian Sea, largely controlled by the Atlantic inflow via the eastern branch of the NAC.

In the Reykjanes Ridge area, influenced by the western branch of the NAC and the IC, the proxy records seem not to converge to a common pattern. For example, Solignac et al. (2004) report relatively stable temperature superimposed by millennial-scale oscillations consistent with the ones identified by Bond et al. (1997). The earlier diatom-based SST record from core LO0914 from the western flank of the Reykjanes Ridge for the period 800 BC-AD 1600 show a similar scale SST variability and a warming trend in agreement with Rapid 21-COM though relatively warmer SST for interval AD 850-1050 (Andersen et al. 2004b; Berner et al. 2008). Near-surface summer SST and salinity reconstructions from core RAPiD-12-1K from the South Iceland rise, located to the northwest of Rapid 21-COM site, reveal persistent positive trends since $\sim 4 \mathrm{kyr}$ BP (Thornalley et al. 2009). At the same time, foraminifer-based summer SST reconstruction from another site MD99-2251 (Farmer et al. 2008) close to Rapid 21-COM indicates highly variable near-surface temperature conditions without a pronounced trend during the period of overlap with our Rapid 21-COM record.

Results from southwest Greenland show a similar SST pattern with Rapid 21-COM indicating an increased advection of warm Atlantic water by the West Greenland Current during the northeastern North Atlantic cooling episodes (e.g., LIA) (Seidenkrantz et al. 2007). In contrast, during the northeastern North Atlantic warming intervals (e.g., MWP) of the past $3000 \mathrm{yr}$, the Atlantic water component of the West Greenland Current was low.

Several SST records based on different proxies (Eiríksson et al. 2000, 2006; Knudsen et al. 2004; Sicre et al. 2008; Ran et al. 2010) from the North Iceland shelf show different SST variability compared with the records from the northern subpolar North Atlantic though the shelf is affected by an anticyclonically flowing northern branch of the IC around Iceland (Fig. 1). However, the SST records correlate better with the records from the northeast subpolar North Atlantic and the Norwegian Sea. The hydrographic variability is larger to the north of Iceland owing to the influence of the Arctic EIC; the SST pattern to the north of Iceland may therefore be linked with the oceanic forcing standing behind SST variations in the NE Atlantic sector and the Nordic Seas.

\section{c. Possible forcing mechanisms behind the SST variability}

A number of forcing factors, both internal and external, have been proposed to control the SST variability in the subpolar North Atlantic during the late Holocene. It includes 1) solar forcing on sub-Milankovitch time scales (Bond et al. 2001; Weber et al. 2004; Berner et al. 2008; Berner et al. 2011; Swingedouw et al. 2011), 2) volcanic forcing (e.g., Bradley et al. 2003; Otterå et al. 2010), 3) internal variability of the AMOC (Delworth and Mann 2000; Junglaus et al. 2005; Hofer et al. 2011), 4) variations of the Atlantic inflow controlled by subpolar gyre dynamics (Häkkinen and Rhines 2004; Hátún et al. 2005; Thornalley et al. 2009), 5) oscillations and input of cold freshwater from the Labrador Sea area and the EGC (Bond et al. 1997; Andersen et al. 2004b; Solignac et al. 2004; Berner et al. 2008), 6) a close coupling between the surface and deep waters (Berner et al. 2008; Hall et al. 2010), and 7) the NAO from interannual to multidecadal scales (Cayan 1992; Marshall et al. 2001; Flatau et al. 2003; Miettinen et al. 2011). However, which of these factors should be regarded as causes or effects is still debated.

The results of climate modeling support the proxyinferred spatial heterogeneity of time variations in sea surface conditions across the northern North Atlantic in the late Holocene. The studies of Weber et al. (2004), Rahmstorf et al. (2005), Goosse and Renssen (2006), and Hofer et al. (2011) suggest a decreasing orbital forcing of the late Holocene, attaining since $3 \mathrm{kyr} \mathrm{BP}$ some $11 \mathrm{~W} \mathrm{~m}^{-2}$ in June-August, or $\sim 1.2 \mathrm{~W} \mathrm{~m}^{-2}$ in the annual mean at $65 \mathrm{~N}^{\circ}$, to drive a more vigorous AMOC and partly offset the cooling tendency through increased northward oceanic heat flux. The process is expected to diminish the cooling trend in CR948/2011 in the Norwegian Sea and promote warming at the Rapid 21-COM site in the subpolar North Atlantic since the intensification of the AMOC in the North Atlantic largely occurs due to stronger convection and NADW formation in the Labrador Sea. The latter is associated with a strengthened SPG and results in an increased advection of warm and saline Atlantic water (Irminger Seawater) by the West 
Greenland Current from the Reykjanes Ridge area (Seidenkrantz et al. 2007). An increase in deep-water flow vigor across the Iceland-Scotland ridge (Bianchi and McCave 1999) and near-surface salinity and temperature to the south of Iceland since $3 \mathrm{kyr}$ BP (Sec. 5b) support an inference of a stronger eastern branch of the AMOC. The evidences of the persistent late Holocene changes in the western branch of AMOC are, however, rather inconsistent. A decrease in freshwater flux from the Arctic through Denmark Strait (Solignac et al. 2006; Thornalley et al. 2009) and farther to the west by the WGC, a cooling of slope waters off Newfoundland (Sachs 2007) concurs with a tendency toward freshening in the Labrador Sea (Thornalley et al. 2009). It precludes reaching a rigorous conclusion about the overall evolution of the meridionally integrated AMOC in the late Holocene.

Berner et al. (2011) suggested that the abrupt changes in CR 948/2011 aSST during the last 3000 yr could be related with transitions between the semistable states of the AMOC. These transitions, triggered by freshwater flux anomalies from the Arctic as a conduit of weak fluctuations in solar forcing, occur due to a nonlinear behavior of the thermohaline circulation (THC) (a stochastic resonance phenomenon). Insolation-driven variations in lower-stratospheric ozone production with "downstream" effects on polar tropospheric circulation can represent a complementary atmospheric amplification mechanism (Haigh 1996). The proposed changes in the regimes of the AMOC (e.g., Hall and Stouffer 2001; Renssen et al. 2005, 2006; Jongma et al. 2007; Schulz et al. 2007; Hofer et al. 2011) involve relocation of the areas of the NADW formation, implying a lasting reorganization of the oceanic circulation and profound impact on a regional climate. We note that such modeling studies still propose rather a conceptual framework. Relatively simplistic model designs and different experiment setup as well as lack of high quality proxy-based constraints condition some spatial dissimilarity in causal factors and the footprints of shifts between the modes.

The atmospheric feedback processes may play an important role in modulating the longer-term changes in the North Atlantic SST through a sustained particular phase of the NAO. The link between the summer NAO and aSST at the Rapid 21-COM core site was earlier demonstrated by Miettinen et al. (2011) with a positive summer NAO phase associated with colder aSST after AD 1770. The location of two cores implies opposite anomalies in SST to emerge on the typical NAO (i.e., annual to decadal) time scales in response to the NAO related anomalous atmospheric heat fluxes (Marshall et al. 2001; Fig. 7). The hint to a positive correlation between the summer NAO and CR 948/2011 aSST arise from the comparison of the series. Yet, the shortness of the available summer NAO data as well as lower than for Rapid 21-COM temporal resolution prevents us from reaching the robust conclusions similar to those inferred for the core from the Reykjanes Ridge area.

Regressing the detrended Rapid 21-COM aSST onto the aNAO index for AD 1773-2004, which correspond to the ultrahigh-resolution section of the core (Miettinen et al. 2011), yields $0.14^{\circ} \mathrm{C}$ (per unit NAO). The correlation of -0.45 between the series set to a common decadal time scale indicates that summer NAO accounts for some $20 \%$ of aSST variability, which is higher than the estimates made by Folland et al. (2009) for this location. It demonstrates that at these time scales the summer NAO is important but not the only factor in driving the North Atlantic SST variability.

The issue of the relative role of the NAO at the secular scales and longer is still controversial. It has been suggested that dynamics underlying the NAO cannot generate a persistent multidecadal- and longer-scale tripole SST pattern reminiscent of seasonal to interannual NAO imprint, in particular, due to the effects of winddriven oceanic advection of heat and salt (e.g., Lohmann et al. 2009). It points, therefore, to a major role of oceanic circulation changes in generating SST anomalies reminiscent of the NAO pattern like the one that may have prevailed during the MWP (Trouet et al. 2009).

\section{Conclusions}

Comparison of summer sea surface conditions at two sites located under the influence of western and eastern branches of the NAC depicts the spatially heterogeneous pattern of climate evolution in the northern North Atlantic in the Late Holocene. Approximately 2800-yrlong diatom-based aSST reconstructions from the northern subpolar North Atlantic (core Rapid 21-COM, the Reykjanes Ridge) and the Norwegian Sea (core CR 948/ 2011, the Vøring Plateau) show persistent opposite trends toward warming on the Reykjanes Ridge and cooling in the Vøring Plateau. An apparent tendency to coherent antiphased aSST variations between the sites is also revealed for the shorter time scales, implying an aSST seesaw between the northern subpolar North Atlantic and the Norwegian Sea to operate during the late Holocene.

The coherence analysis demonstrates nearly antiphased variations between the aSST series in the submillennial band of 640-960 yr. A similar conclusion, but with an intermittent phase locking, is drawn for the shorter time scales of the aSST variability of 200-450 yr. This aSST seesaw might have had a strong influence on climate in northwest Europe. In particular, a generally 
warmer aSST prevailed in the subpolar North Atlantic during the LIA, while colder surface waters were observed in the Norwegian Sea. The reversed pattern characterized the period associated with the Medieval Warming.

Coupled changes in aSST between the northern subpolar North Atlantic and the Norwegian Sea indicate common driving forces behind the observed variability. The emerging spatial pattern of changes resembles the one predicted by modeling studies and associated with rapid changes in the regimes of the North Atlantic overturning circulation. These transitions may have been triggered by solar-induced Arctic freshwater outflow anomalies and are related with the lasting reorganizations of oceanic circulation and the areas of deep-water formation. Induced by the SST changes, the persistent anomalies of atmospheric circulation analogous to the preferentially positive NAO phase during the MWP may have further amplified and sustained the aSST seesaw between the study sites. However, a further confirmation and assessment on the details on the proposed mechanism is required; the high-resolution proxies of past oceanic climate as well as modeling studies would be of critical importance.

Acknowledgments. We thank three anonymous reviewers for their constructive comments and suggestions. We also thank Dorthe Klitgaard-Kristensen for helpful comments. This work was financed by the Norwegian Research Council, through the NARE project "Holocene Antarctic climate variability from ice and marine sediment cores: insights to ocean-atmosphere interaction" and the EU-funded European Project for Ice Coring in Antarctica (EPICA).

\section{REFERENCES}

Andersen, C., N. Koç, A. Jennings, and J. T. Andrews, 2004a: Nonuniform response to the major surface currents in the Nordic Seas to insolation forcing: Implications for the Holocene climate variability. Paleoceanography, 19, PA2003, doi:10.1029/2002PA000873.

_,$\ldots$, and M. Moros, 2004b: A highly unstable Holocene climate in the subpolar North Atlantic: Evidence from diatoms. Quat. Sci. Rev., 23, 2155-2166.

Andersson, C., F. S. R. Pausata, E. Jansen, B. Riserobakken, and R. J. Telford, 2010: Holocene trends in the foraminifer record from the Norwegian Sea and the North Atlantic Ocean. Climate of the Past, 6, 179-193.

Andrews, J. T., and J. Giraudeau, 2003: Multi-proxy records showing significant Holocene environmental variability: The inner N. Iceland shelf (Húnaflói). Quat. Sci. Rev., 22, 175-193.

Bendat, J. S., and A. G. Piersol, 1986: Random Data. Wiley, 566 pp.

Berner, K. S., N. Koç, D. Divine, F. Godtliebsen, and M. Moros, 2008: A decadal-scale Holocene sea surface temperature record from the subpolar North Atlantic constructed using diatoms and statistics and its relation to other climate parameters. $\mathrm{Pa}$ leoceanography, 23, PA2210, doi:10.1029/2006PA001339.

,$- \ldots$, F. Godtliebsen, and D. Divine, 2011: Holocene climate variability of the Norwegian Atlantic Current during high and low solar insolation forcing. Paleoceanography, 26, PA2220, doi:10.1029/2010PA002002.

Bianchi, G. G., and I. N. McCave, 1999: Holocene periodicity in North Atlantic climate and deep-ocean flow south of Iceland. Nature, 397, 515-517.

Birks, C. J. A., and N. Koç, 2002: A high-resolution diatom record of late-Quaternary sea surface temperatures and oceanographic conditions from the eastern Norwegian Sea. Boreas, 31, 323-344.

Bjerknes, J., 1964: Atlantic air-sea interaction. Adv. Geophys., 10, $1-82$.

Boessenkool, K. P., I. R. Hall, H. Elderfield, and I. Yashayaev, 2007: North Atlantic climate and deep-ocean flow speed changes during the last 230 years. Geophys. Res. Lett., 34, L13614, doi:10.1029/2007GL030285.

Bond, G., and Coauthors, 1997: A pervasive millennial-scale cycle in North Atlantic Holocene and glacial climates. Science, 278, 1257-1266.

- and Coauthors, 2001: Persistent solar influence on North Atlantic climate during the Holocene. Science, 294, 21302136.

Bradley, R. S., and P. D. Jones, 1993: 'Little Ice Age' summer temperature variations: Their nature and relevance to recent global warming trends. Holocene, 3, 367-376.

—, M. K. Hughes, and H. F. Diaz, 2003: Climate in Medieval time. Science, 302, 404-405.

Broecker, W. S., 2000: Was a change in thermohaline circulation responsible for the Little Ice Age? Proc. Natl. Acad. Sci. USA, 97, 1339-1342.

Cayan, D. R., 1992: Latent and sensible heat flux anomalies over the North Oceans: Driving the sea surface temperature. J. Phys. Oceanogr., 22, 859-881.

Chaudhuri, P., and J. S. Marron, 1999: SiZer for exploration of structures in curves. J. Amer. Stat. Assoc., 94, 807-823.

Crowley, T. J., 2000: Causes of climate change over the past 1000 years. Science, 289, 270-277.

Cunningham, S. A., and Coauthors, 2007: Temporal variability of the Atlantic meridional overturning circulation at $26.5^{\circ} \mathrm{N}$. Science, 317, 935-938.

Dahl, K. A., A. J. Broccoli, and R. J. Stouffer, 2005: Assessing the role of North Atlantic freshwater forcing in millennial scale climate variability: A tropical Atlantic perspective. Climate Dyn., 24, 325-346.

Dansgaard, W., and Coauthors, 1993: Evidence for general instability of past climate from a $250-\mathrm{Kyr}$ ice-core record. $\mathrm{Na}$ ture, 364, 218-220.

Delworth, T. L., and M. E. Mann, 2000: Observed and simulated multidecadal variability in the Northern Hemisphere. Climate Dyn., 16, 661-676.

deMenocal, P. B., J. Ortiz, T. P. Guilderson, and M. Sarnthein, 2000: Coherent high- and low-latitude climate variability during the Holocene Warm Period. Science, 288, 2198-2202.

Denton, G. H., and W. Karlén, 1973: Holocene climate variationsTheir pattern and possible cause. Quat. Res., 3, 155-205.

Divine, D. V., and C. Dick, 2006: Historical variability of sea ice edge position in the Nordic Seas. J. Geophys. Res., 111, C01001, doi:10.1029/2004JC002851.

, N. Koç, E. Isaksson, F. Godliebsen, X. Crosta, and S. Nielsen, 2010: Holocene climate variability from ice and marine 
sediment cores: Insights to ocean-atmosphere interactions. Quat. Sci. Rev., 29, 303-312.

Eiríksson, J., K. L. Knudsen, H. Haflidason, and J. Heinemeier, 2000: Chronology of late Holocene climatic events in the northern Atlantic based on AMS ${ }^{14} \mathrm{C}$ dates and tephra markers from the volcano Hekla, Iceland. J. Quat. Sci., 15, 573-580.

- , and Coauthors, 2006: Variability of the North Atlantic Current during the last 2000 years based on shelf bottom water and sea surface temperatures along an open ocean/shallow marine transect in Western Europe. Holocene, 16, 1012-1024.

EPICA Community Members, 2006: One-to-one coupling of glacial climate variability in Greenland and Antarctica. Nature, 444, 195-198.

Farmer, E. J., M. R. Chapman, and J. E. Andrews, 2008: Centennial-scale Holocene North Atlantic surface temperatures from $\mathrm{Mg} / \mathrm{Ca}$ ratios in Globigerina bulloides. Geochem. Geophys. Geosyst., 9, Q12029, doi:10.1029/2008GC002199.

Flatau, M. K., L. Talley, and P. P. Niiler, 2003: The North Atlantic Oscillation, surface current velocities, and SST changes in the subpolar North Atlantic. J. Climate, 16, 2355-2369.

Folland, C. K., J. Knight, H. W. Linderholm, D. Fereday, S. Ineson, and J. W. Hurrell, 2009: The summer North Atlantic oscillation: Past, present, and future. J. Climate, 22, 1082-1108.

Fratantoni, D. M., 2001: North Atlantic surface circulation during the 1990's observed with satellite-tracked drifters. J. Geophys. Res., 106 (C10), 22 067-22 093.

Goosse, H., and H. Renssen, 2006: Regional response of the climate system to solar forcing: The role of the ocean. Space Sci. Rev., 125, 227-235, doi:10.1007/s11214-006-9059-0.

Greene, C. H., A. J. Pershing, T. M. Cronin, and N. Ceci, 2008: Arctic climate and its impacts on the ecology of the North Atlantic. Ecology, 89, s24-s38.

Grinsted, A., J. Moore, and S. Jevrejeva, 2004: Application of the cross wavelet transform and wavelet coherence to geophysical time series. Nonlinear Processes Geophys., 11, 561-566.

Grove, J. M., 1988: The Little Ice Age. Methuen, 520 pp.

Haigh, J. D., 1996: The impact of solar variability on climate. Science, 272, 981-984.

Häkkinen, S., and P. B. Rhines, 2004: Decline of subpolar North Atlantic circulation during the 1990s. Science, 304, $555-559$.

Hall, A., and R. J. Stouffer, 2001: An abrupt climate event in a coupled ocean-atmosphere simulation without external forcing. Nature, 409, 171-174.

Hall, I. R., K. P. Boessenkool, S. Barker, I. N. McCave, and H. Elderfield, 2010: Surface and deep ocean coupling in the subpolar North Atlantic during the last 230 years. Paleoceanography, 25, PA2101, doi:10.1029/2009PA001886.

Hansen, B., and S. Østerhus, 2000: North Atlantic-Nordic Seas exchanges. Prog. Oceanogr., 45, 109-208.

Hátún, H., A. B. Sand $\varnothing$, H. Drange, B. Hansen, and H. Valdimarsson, 2005: Influence of the North Atlantic subpolar gyre on the thermoline circulation. Science, 309, 1841-1844.

Hegerl, G. C., and Coauthors, 2007: Understanding and attributing climate change. Climate Change 2007: The Physical Science Basis, S. Solomon et al., Eds., Cambridge University Press, 663-745.

Hofer, D., C. C. Raible, and T. F. Stocker, 2011: Variations of the Atlantic meridional overturning circulation in control and transient simulations of the last millennium. Climate of the Past, 7, 133-150, doi:10.5194/cp-7-133-2011.

Jongma, J. I., M. Prange, H. Renssen, and M. Schulz, 2007: Amplification of Holocene multicentennial climate forcing by mode transitions in North Atlantic overturning circulation. Geophys. Res. Lett., 34, L15706, doi:10.1029/2007GL030642.

Junglaus, J. H., H. Haak, M. Latif, and U. Mikolajewicz, 2005: Arctic-North Atlantic interactions and multidecadal variability of the meridional overturning circulation. J. Climate, 18, 4013-4031.

Klitgaard-Kristensen, D., H. P. Sejrup, and H. Haflidason, 2001: The last 18-kyr fluctuations in Norwegian Sea conditions and implications for the magnitude of climatic change: Evidence from the North Sea. Paleoceanography, 16, 455-467.

Knight, J. R., R. J. Allan, C. K. Folland, M. Vellinga, and M. E. Mann, 2005: A signature of persistent natural thermohaline circulation cycles in observed climate. Geophys. Res. Lett., 32, L20808, doi:10.1029/2005GL024233.

Knudsen, K. L., J. Eiríksson, E. Jansen, H. Jiang, F. Rytter, and E. R. Gudmundsdottir, 2004: Palaeooceanographic changes off North Iceland through the last 1200 years: Foraminifera, stable isotopes, diatoms and ice rafted debris. Quat. Sci. Rev., 23, 2231-2246.

Koç, N., and E. Jansen, 1994: Response of the high-latitude Northern Hemisphere to orbital climate forcing: Evidence from the Nordic Seas. Geology, 22, 523-526.

— $—$, and H. Haflidason, 1993: Paleoceanographic reconstruction of surface ocean conditions in the Greenland, Iceland, and Norwegian Seas through the last 14 ka based on diatoms. Quat. Sci. Rev., 12, 115-140.

Koç-Karpuz, N., and H. Schrader, 1990: Surface sediment diatom distribution and Holocene paleo-temperature variations in the Greenland, Iceland and Norwegian Seas through the last $14 \mathrm{ka}$ based on diatoms. Paleoceanography, 5, 557-580.

Lamb, H. H., 1965: The early Medieval warm epoch and its sequel. Palaeogeogr. Palaeoclimatol. Palaeoecol., 1, 13-37.

Latif, M., and Coauthors, 2004: Reconstructing, monitoring, and predicting multidecadal-scale changes in the North Atlantic thermohaline circulation with sea surface temperature. J. Climate, 17, 1605-1614.

Lohmann, K., H. Drange, and M. Bentsen, 2009: Response of the North Atlantic subpolar gyre to persistent North Atlantic oscillation like forcing. Climate Dyn., 32, 273-285, doi:10.1007/ s00382-008-0467-6.

Mann, M. E., and P. D. Jones, 2003: Global surface temperatures over the past two millennia. Geophys. Res. Lett., 30, doi:10.1029/ 2003GL017814.

_ Z Z. Z. Zhang, M. K. Hughes, R. S. Bradley, S. K. Miller, S. Rutherford, and F. Ni, 2008: Proxy-based reconstructions of hemispheric and global surface temperature variations over the past two millennia. Proc. Natl. Acad. Sci. USA, 105, $13252-$ 13 257, doi:10.1073/pnas.0805721105.

Marchal, O., and Coauthors, 2002: Apparent long-term cooling of the sea surface in the northeast Atlantic and Mediterranean during the Holocene. Quat. Sci. Rev., 21, 455-483.

Marshall, J., and Coauthors, 2001: North Atlantic climate variability: Phenomena, impacts and mechanisms. Int. J. Climatol., 21, 1863-1898.

Mauritzen, C., and S. Häkkinen, 1997: Influence of sea ice on the thermohaline circulation in the Arctic-North Atlantic Ocean. Geophys. Res. Lett., 24, 3257-3260.

Miettinen, A., N. Koç, I. R. Hall, F. Godtliebsen, and D. Divine, 2011: North Atlantic sea surface temperatures and their relation to the North Atlantic Oscillation during the last 230 years. Climate Dyn., 36, 533-543, doi:10.1007/s00382-0100791-5. 
Moberg, A., D. M. Sonechin, K. Holmgren, N. M. Datsenko, and W. Karlén, 2005: Highly variable Northern Hemisphere temperatures reconstructed from low and high resolution proxy data. Nature, 433, 613-617.

Orvik, K. J., and P. Niiler, 2002: Major pathways of Atlantic water in the northern North Atlantic and Nordic Seas toward Arctic. Geophys. Res. Lett., 29, 1896, doi:10.1029/2002GL015002.

Otterå, O. H., M. Bensen, H. Drange, and L. Suo, 2010: External forcing as a metronome for Atlantic multidecadal variability. Nat. Geosci., 3, 688-694, doi:10.1038/NGEO955.

Rahmstorf, S., and Coauthors, 2005: Thermohaline circulation hysteresis: A model intercomparison. Geophys. Res. Lett., 32, L23605, doi:10.1029/2005GL023655.

Ran, L., H. Jiang, K.-L. Knudsen, and J. Eiríksson, 2010: Diatombased reconstruction of palaeoceanographic changes on the North Icelandic shelf during the last millennium. Palaeogeogr. Palaeoclimatol. Palaeoecol., 302, 109-119, doi:10.1016/j.palaeo. 2010.02.001.

Renssen, H., H. Goosse, and T. Fichefet, 2005: Contrasting trends in North Atlantic deep-water formation in the Labrador Sea and Nordic Seas during the Holocene. Geophys. Res. Lett., 32, L08711, doi:10.1029/2005GL022462.

,-- , and R. Muscheler, 2006: Coupled climate model simulation of Holocene cooling events: Solar forcing triggers oceanic feedback. Climate of the Past, 2, 79-90.

Richter, T. O., F. J. C. Peeters, and T. C. E. van Weering, 2009: Late Holocene (0-2.4 ka BP) surface water temperature and salinity variability, Feni Drift, NE Atlantic Ocean. Quat. Sci. Rev., 28, 1941-1955.

Risebrobakken, B., E. Jansen, C. Andersson, E. Mjelde, and K. Hevrøy, 2003: A high-resolution study of Holocene paleoclimatic and paleoceanographic changes in the Nordic Seas. Paleoceanography, 18, 1017, doi:10.1029/2002PA000764.

Ruddiman, W. F., and L. K. Glover, 1975: Subpolar North Atlantic circulation at 9300 BP: Faunal evidences. Quat. Res., 5, 361389.

Ruppert, D., S. J. Sheather, and M. P. Wand, 1995: An effective bandwidth selector for local least squares regression. J. Amer. Stat. Assoc., 90, 1257-1270.

Sachs, J. P., 2007: Cooling of Northwest Atlantic slope waters during the Holocene. Geophys. Res. Lett., 34, L03609, doi:10.1029/ 2006GL028495.

Schrader, H. J., and R. Gersonde, 1978: Diatoms and Silicoflagellates. Micropaleontological counting methods and techniques-An exercise on an eight meters section of the lower Pliocene of Capo Rossello. Utrecht Micropaleontol. Bull., 17, 129-176.

Schulz, M., and M. Mudelsee, 2002: REDFIT: Estimating red-noise spectra directly from unevenly spaced paleoclimatic time series. Comput. Geosci., 28, 421-426.
_- M. Prange, and A. Klocker, 2007: Low-frequency oscillations of the Atlantic Ocean meridional overturning circulation in a coupled climate model. Climate of the Past, 3, 97-107.

Seidenkrantz, M. S., S. Aagaard-Sørensen, H. Sulsbrück, A. Kuijpers, K. G. Jensen, and H. Kunzendorf, 2007: Hydrography and climate of the last 4400 years in a SW Greenland. Holocene, 17, 387-401.

Shindell, D. T., G. A. Schmidt, M. E. Mann, D. Rind, and A. Waple, 2001: Solar forcing of regional climate change during the Maunder Minimum. Science, 294, 2149-2152.

, — - R. I. Miller, and M. E. Mann, 2003: Volcanic and solar forcing of climate change during the preindustrial era. J. Climate, 16, 4094-4107.

Sicre, M.-A., and Coauthors, 2008: A 4500-year reconstruction of sea surface temperature variability at decadal time-scales off North Iceland. Quat. Sci. Rev., 27, 2041-2047.

, and Coauthors, 2011: Sea surface temperature variability in the subpolar Atlantic over the last two millennia. Paleoceanography, 26, PA4218, doi:10.1029/2011PA002169.

Solignac, S., A. Vernal, and C. Hillaire-Marcel, 2004: Holocene seasurface conditions in the North Atlantic - Contrasted trends and regimes in the western and eastern sectors (Labrador Sea vs. Iceland Basin). Quat. Sci. Rev., 23, 319-334.

- J. Giraudeau, and A. de Vernal, 2006: Holocene sea surface conditions in the western North Atlantic: Spatialand temporal heterogeneities. Paleoceanography, 21, PA2004, doi:10.1029/ 2005PA001175.

Swingedouw, D., L. Terray, C. Cassou, A. Voldoire, D. Salas-Mélia, and J. Servonnat, 2011: Natural forcing of climate during the last millennium: Fingerprint of solar variability. Climate Dyn., 36, 1349-1364, doi:10.1007/s00382-010-0803-5.

ter Braak, C. J. F., and S. Juggins, 1993: Weighted averaging partial least squares regression (WA-PLS); An improved method for reconstructing environmental variables from species assemblages. Hydrobiologia, 269-270, 485-502.

Thornalley, D. J. R., H. Elderfield, and I. N. McCave, 2009: Holocene oscillations in temperature and salinity of the surface subpolar North Atlantic. Nature, 457, 711-714.

Torrence, C., and G. Compo, 1998: A practical guide to wavelet analysis. Bull. Amer. Meteor. Soc., 79, 61-78.

Trouet, V., J. Esper, N. E. Graham, A. Baker, J. D. Scourse, and D. C. Frank, 2009: Persistent positive North Atlantic Oscillation mode dominated the Medieval climate anomaly. Science, 324, 78-80.

Vellinga, M., and R. A. Wood, 2002: Global climatic impacts of a collapse of the Atlantic thermohaline circulation. Climatic Change, 54, 251-267.

Weber, S. L., T. J. Crowley, and G. van der Schrier, 2004: Solar irradiance forcing of centennial climate variability during the Holocene. Climate Dyn., 22, 539-553, doi:10.1007/s00382004-0396-y. 